\title{
Magnesium Sulfate Effect on Fetal Umbilical Artery and Middle Cerebral Artery Doppler Indicies in Women with Severe Preeclampsia and Eclampsia
}

\author{
Nermeen Mohamed Hefila \\ Department of Obstetrics and Gynecology, Faculty of Medicine, University of Alexandria, Alexandria, Egypt \\ Email: nermeenptsbasem81@gmail.com
}

How to cite this paper: Hefila, N.M. (2021) Magnesium Sulfate Effect on Fetal Umbilical Artery and Middle Cerebral Artery Doppler Indicies in Women with Severe Preeclampsia and Eclampsia. Open Journal of $O b$ stetrics and Gynecology, 11, 636-645. https://doi.org/10.4236/ojog.2021.115059

Received: May 2, 2021

Accepted: May 24, 2021

Published: May 27, 2021

\section{Copyright $\odot 2021$ by author(s) and} Scientific Research Publishing Inc. This work is licensed under the Creative Commons Attribution International License (CC BY 4.0).

http://creativecommons.org/licenses/by/4.0/

\section{(c) (i) Open Access}

\begin{abstract}
Objective: To study $\mathrm{MgSO}_{4}$ effect on fetal MCA and UA blood flow changes using Doppler ultrasound in cases of severe PET and eclampsia. Materials and Methods: A total of 40 patients with severe PET admitted to El-Shatby Maternity University Hospital, Alexandria (Egypt) were examined before and after administration of $\mathrm{MgSO}_{4}$ using Doppler study to measure fetal MCA and UA blood flow changes. Results: After administration of $\mathrm{MgSO}_{4}$, the mean RI of UA, PI of UA showed a statistically significant decrease $(\mathrm{P}<$ $0.001)$ also the systolic-diastolic ratio $(\mathrm{p}=0.001)$. Mean resistivity index $(\mathrm{RI})$ cerebral showed a statistically significant increasing $(P=0.001)$, pulsatility index (PI)-cerebral and the systolic-diastolic ratio showed a statistically significant increasing $(\mathrm{P}<0.001)$. The $\mathrm{C} / \mathrm{U}$ (cerebroumblical) ratio increased after the treatment $(\mathrm{P}<0.001)$. Conclusions: Infusion of $\mathrm{MgSO}_{4}$ significantly decreases the fetal RI, PI, SDR umbilical and increases the fetal RI, PI, SDR MCA and increases cerebroumblical ratio indices obtained by Doppler examinations.
\end{abstract}

\section{Keywords}

Doppler Ultrasound, Eclampsia, Magnesium Sulfate, Preeclampsia

\section{Introduction}

Preeclampsia is diagnosed when the systolic blood pressure is $\geq 140 \mathrm{mmHg}$ or diastolic blood pressure is $\geq 90 \mathrm{mmHg}$ associated proteinuria $\geq 300 \mathrm{mg}$ in 24 hour urine and diagnosed 20 weeks of gestation and it is usually recognized as a systemic disorder resolving with delivery or soon thereafter [1]. 
PET and eclampsia are among the most important diseases of pregnancy causing maternal morbidity and mortality associated with high vascular resistance due to vascular spasm with impaired placental blood flow [2].

Preeclampsia complicates $3 \%$ - 5\% of all pregnancies, but approximately $7 \%$ of those in nulliparas, it remains a major disease causing of maternal morbidity and mortality [3] [4] [5].

This disease can cause many fetal and maternal complications [6] [7] [8] [9].

$\mathrm{MgSO}_{4}$ is the best drug used in treatment of severe PET and eclampsia and prevent maternal and fetal complications [10] [11]. Effect of $\mathrm{MgSO}_{4}$ on the brain vascular blood flow is still unclear as it may reduce the vasospasm [12] [13] [14] [15].

The $\mathrm{MgSO}_{4}$ changes vascular permeability and reduces the edema [10]. It seems to have no adverse effects on the fetus [16], but in response to $\mathrm{MgSO}_{4}$ injection, fetal brain perfusion may be also altered [17].

Doppler ultrasound is the best mood to study the mechanisms by which PET affects the fetal circulation [18] [19]. Arterial changes evaluated with Doppler ultrasound can show how the fetus is heamodynamically adapted the changes in PET [20] [21].

Increase in UA PI is associated with decreased fetal perfusion. If the situation continues, MCA RI will decrease [22].

In PET, usually we measure the UA doppler changes but recent studies showed that measuring also MCA Doppler changes is adding more beneficial information about fetal wellbeing state [23] [24] [25]. With using the C/U ratio (cerebroumblical ratio) is superior in detecting fetal circulation changes and so prognosis [25] [26] [27] [28]. $\mathrm{MgSO}_{4}$ effect on the fetal adaptive changes in PET is one of the most important research issues [29].

Aim of the Work: To study $\mathrm{MgSO}_{4}$ effect on fetal MCA and UA blood flow changes using Doppler ultrasound in cases of severe PET and eclampsia.

\section{Material and Methods}

In this study, all the participants were evaluated before and after $\mathrm{MgSO}_{4}$ administration. This study was approved by the ethics committee of the Faculty of Medicine University of Alexandria.

Pregnant cases with sever PET and eclamptic fits who attended to El-Shatby Maternity University Hospital during the period between December 2019 and December 2020 were involved in the study. Inclusion criteria were: Age in the range of 18 - 40 years, Singleton pregnancy, Any gravidity or parity, Gestational age equal to or above 28 weeks, Systolic blood pressure $\geq 160 \mathrm{mmHg}$ or diastolic pressure $\geq 110 \mathrm{mmHg}$ on two occasion six hours or more apart on bed rest, Preeclampsia with new onset grand seizures [30], Spontaneous pregnancy and One or more of the following [30] [31] [32] [33]: (Proteinuria of 24 hour urine of at least $5 \mathrm{~g}$ of protein or $3+$ or more on two random samples collected four or more hours apart, Sudden oliguria. Central nervous system disturbances, Pul- 
monary edema or cyanosis, Epigastric or right upper quadrant pain, Liver dysfunction (increase serum levels of SGOT and SGPT), Thrombocytopenia < $100,000 / \mathrm{cmm}$, Fetal growth restriction calculated by Hadlock formula [34]. Exclusion Criteria were: Cases with other systemic disease (e.g., diabetes, hypertension, and autoimmune disorders), multiple pregnancy, Fetuses with congenital anomaly, History of taking opium, smoking and twin pregnancy.

The goal of the study and the method were described to all patients and written consent form was taken prior to the initiation of study.

After admission of the patient, the following was done:

1) Complete history taking.

2) General and local examination.

3) Color Doppler ultrasound of fetal UA and MCA, the cerebro-umbilical ratio (middle cerebral artery resistance index/umbilical artery resistance index), pulsatility index (PI) and S/D ratio will were evaluated.

4) After initial assessment, the obstetrician gives the loading and maintenance dose of $\mathrm{MgSO}_{4}$. The loading dose has $4 \mathrm{~g}$ of $\mathrm{MgSO}_{4}$ in $250 \mathrm{ml}$ saline intravenously infusion for $20 \mathrm{~min}$ and then the maintenance dose which has $8 \mathrm{~g} \mathrm{MgSO}_{4}$ in $500 \mathrm{ml}$ saline/8 hours.

Then again MCA and UA Doppler evaluation was done to evaluate blood flow changes.

\section{Outcome}

This result was compared with APGAR Score of the baby and the out-come of the mother.

\section{Results}

\section{1) Umbilical artery Doppler indices}

There were statistical significant differences between umbilical artery PI, RI and cerebroplacental ratio with administration of $\mathrm{MgSO}_{4}(\mathrm{p}<0.001)$; as shown in Table 1.

\section{2) Middle cerebral artery [MCA] Doppler indices}

There were statistical significant differences between MCA them $(\mathrm{p}<0.001)$; as shown in Table 2.

3) Relation between ultrasonographic assessment of amount of liquor and cerebro-placental ratio $(\mathrm{Cl} U)$ before and after $\mathrm{mgSO}_{4}$ administration

The Cerebro-placental ratio(C/U ratio) before and after $\mathrm{mgSO}_{4}$ has statistical significant differences in both groups $(\mathrm{p}=0.009)$ and $(\mathrm{p}=0.004)$ with no statistical significant differences between both of them $(p=0.211)$; as shown in Table 3.

4) Relation between estimated fetal weight (gm) and cerebro-placental ratio $\left(\mathrm{Cl} U\right.$ ) before and after $\mathrm{mgSO}_{4}$ administration

There were 28 cases of normal fetal biometry and 12 case of intrauterine growth restriction. As shown in Table 4.

The Cerebro-placental ratio ( $\mathrm{C} / \mathrm{U}$ ratio) before and after $\mathrm{mgSO}_{4}$ has statistical 
Table 1. Comparison between umbilical artery ultrasonographic Doppler evaluation before and after $\mathrm{MgSO}_{4}$ administration $(\mathrm{n}=40)$.

\begin{tabular}{lccc}
\hline \multicolumn{1}{c}{ Umbilical artery } & Before & After & p \\
\hline RI (resistance index) & & & \\
Min. - Max. & $0.46-1.0$ & $0.4-0.90$ & $<0.001^{*}$ \\
Mean \pm SD. & $0.69 \pm 0.15$ & $0.63 \pm 0.12$ & \\
Median & 0.66 & 0.62 & \\
PI (pulsatility index) & & & $<0.001^{*}$ \\
Min. - Max. & $0.6-2.16$ & $0.40-2.0$ & \\
Mean \pm SD. & $1.16 \pm 0.43$ & $1.05 \pm 0.41$ & \\
Median & 1.08 & 1.0 & \\
SDR (Systolic-diastolic ratio) & & & \\
Min. - Max. & $0.7-7.80$ & $0.8-6.33$ & \\
Mean \pm SD. & $3.30 \pm 1.37$ & $3.03 \pm 1.11$ & \\
Median & 2.90 & 2.69 & \\
\hline
\end{tabular}

$\mathrm{p}$ : $\mathrm{p}$ value for Paired t-test or Wilcoxon signed ranks test for comparing between before and after; ${ }^{*}$ : Statistically significant at $\mathrm{p} \leq 0.05$.

Table 2. Comparison between middle cerebral artery ultrasonographic Doppler evaluation before and after $\mathrm{MgSO}_{4}$ administration $(\mathrm{n}=40)$.

\begin{tabular}{lccc}
\hline \multicolumn{1}{c}{ Umbilical artery } & Before & After & p \\
\hline RI (resistance index) & & & \\
Min. - Max. & $0.06-0.98$ & $0.07-0.90$ & \\
Mean \pm SD. & $0.70 \pm 0.15$ & $0.75 \pm 0.14$ & tp $=0.001^{*}$ \\
Median & 0.73 & 0.78 & \\
PI (pulsatility index) & & & \\
Min. - Max. & $0.1-2.60$ & $0.14-2.70$ & \\
Mean \pm SD. & $1.35 \pm 0.49$ & $1.47 \pm 0.46$ & $\mathrm{Wxp}<0.001^{*}$ \\
Median & 1.29 & 1.44 & \\
SDR (Systolic-diastolic ratio) & & & \\
Min. - Max. & $0.80-10.60$ & $1.0-11.0$ & \\
Mean \pm SD. & $4.0 \pm 1.86$ & $4.31 \pm 1.83$ & $\mathrm{Wxp}<0.001^{*}$ \\
Median & 3.61 & 3.95 &
\end{tabular}

p: $p$ value for Paired t-test or Wilcoxon signed ranks test for comparing between before and after; ${ }^{*}$ : Statistically significant at $\mathrm{p} \leq 0.05$.

significant differences in both groups $(\mathrm{p}=0.013)$ and $(\mathrm{p}=0.008)$ with no statistical significant differences between both of them $(p=0.250)$. As shown in Table 4.

\section{Maternal outcome}

There were no cases of maternal deaths and all cases recovered well. 
Table 3. Relation between ultrasonographic assessment of amount of liquor and cerebro-placental ratio $(\mathrm{C} / \mathrm{U})$ before and after $\mathrm{MgSO}_{4}$ administration.

\begin{tabular}{|c|c|c|c|c|}
\hline \multirow[b]{2}{*}{$\mathrm{C} / \mathrm{U}$ ratio } & \multicolumn{2}{|c|}{ Liquor } & \multirow[b]{2}{*}{$\mathrm{T}$} & \multirow[b]{2}{*}{$\mathrm{p}$} \\
\hline & $\begin{array}{l}\text { Normal } \\
(\mathrm{n}=32)\end{array}$ & $\begin{array}{l}\text { Oligohydramnios } \\
\qquad(\mathrm{n}=8)\end{array}$ & & \\
\hline \multicolumn{5}{|l|}{ Before } \\
\hline Min. - Max. & $0.09-2.13$ & $0.40-1.60$ & & \\
\hline Mean \pm SD. & $1.08 \pm 0.38$ & $1.08 \pm 0.40$ & 0.010 & 0.992 \\
\hline Median & 1.04 & 1.16 & & \\
\hline \multicolumn{5}{|l|}{ After } \\
\hline Min. - Max. & $0.11-2.25$ & $0.62-1.88$ & & \\
\hline Mean \pm SD & $1.20 \pm 0.37$ & $1.31 \pm 0.41$ & 0.716 & 0.478 \\
\hline Median & 1.17 & 1.40 & & \\
\hline p1 & $0.009^{*}$ & $0.004^{*}$ & & \\
\hline \multicolumn{5}{|l|}{$\%$ of change } \\
\hline Mean \pm SD & $15.13 \pm 21.60$ & $26.09 \pm 18.14$ & $\mathrm{U}=91.000$ & 0.211 \\
\hline
\end{tabular}

$t, p: t$ and $p$ values for Student $t$-test for comparing between the two groups; $U, p: U$ and $p$ values for Mann Whitney test for comparing between the two groups; p1:p value for Paired t-test for comparing between before and after in each group; ${ }^{*}$ : Statistically significant at $p \leq 0.05$.

Table 4. Relation between estimated fetal weight (gm) and cerbro-placental ratio (C/U) before and after $\mathrm{MgSO}_{4}$ administration.

\begin{tabular}{|c|c|c|c|c|}
\hline \multirow[b]{2}{*}{$\mathrm{C} / \mathrm{U}$ ratio } & \multicolumn{2}{|c|}{ Estimated fetal weight (gm) } & \multirow[b]{2}{*}{$\mathrm{T}$} & \multirow[b]{2}{*}{$\mathrm{p}$} \\
\hline & $\begin{array}{l}\text { Normal } \\
(n=28)\end{array}$ & $\begin{array}{l}\text { Oligohydramnios } \\
\qquad(\mathrm{n}=12)\end{array}$ & & \\
\hline \multicolumn{5}{|l|}{ Before } \\
\hline Min. - Max. & $0.09-2.13$ & $0.40-1.36$ & & \\
\hline Mean \pm SD & $1.14 \pm 0.40$ & $0.93 \pm 0.27$ & 1.656 & 0.106 \\
\hline Median & 1.14 & 0.91 & & \\
\hline \multicolumn{5}{|l|}{ After } \\
\hline Min. - Max. & $0.11-2.25$ & $0.62-1.88$ & & \\
\hline Mean \pm SD. & $1.27 \pm 0.39$ & $1.12 \pm 0.34$ & 1.141 & 0.261 \\
\hline Median & 1.22 & 1.04 & & \\
\hline $\mathrm{p} 1$ & $0.013^{*}$ & $0.008^{*}$ & & \\
\hline \multicolumn{5}{|l|}{$\%$ of change } \\
\hline Mean \pm SD & $14.81 \pm 20.36$ & $23.18 \pm 22.88$ & $\mathrm{U}=129.000$ & 0.250 \\
\hline
\end{tabular}

$t, p: t$ and $p$ values for Student $t$-test for comparing between the two groups; $U, p: U$ and $p$ values for Mann Whitney test for comparing between the two groups; p1:p value for Paired t-test for comparing between before and after in each group; ${ }^{*}$ : Statistically significant at $\mathrm{p} \leq 0.05$.

\section{Discussion}

Preeclampsia is one of the most important serious diseases of pregnancy and 
occurs in $5 \%$ to $7 \%$ of pregnant women [34].

Doppler mood ultrasonic evaluation is used to evaluate blood flow in fetal vessels [35].

A low index of pulsatility in the MCA associated with fetal decompansation has been described [36].

Because the cerebroumblical ratio is providing information about placental perfusion and about fetal changes so its an important factor in estimating fetal outcome and well being [37].

The objective of this study was to assess the effects of administration of $\mathrm{MgSO}_{4}$ on Doppler parameters of middle cerebral and umbilical arteries in cases of severe PET and eclampsia.

The study was conducted on 40 pregnant female selected from EL Shatby Maternity University Hospital during the period between December 2015 and December 2016.

There were 28 cases with normal fetal growth and 12 cases with intrauterine fetal growth restriction. There was statistically significant improve in the $\mathrm{C} / \mathrm{U}$ ratio after $\mathrm{MgSO}_{4}$ administration in both of them.

Regarding the Doppler indices studied in our study, the injection of $\mathrm{MgSO}_{4}$ could significantly decrease the RI, PI and SD ratio of the umbilical artery, increase the RI, PI and SDR-MCA, thus increase the $\mathrm{C} / \mathrm{U}$ ratio.

Souza, et al., [38], assessed MCA and UA Doppler parameters of the fetus. They agree with our study as regard the umbilical artery only but against it as regard the MCA.

In addition, Souza et al., [38] [39] showed the reduction of PI in the fetal umbilical artery and MCA due to the injection of $\mathrm{MgSO}_{4}$.

Qiao, et al., [40] have found significant changes in parameters after administration of $\mathrm{MgSO}_{4}$. In our study, we found significant improvement of $\mathrm{C} / \mathrm{U}$ ratio after using $\mathrm{MgSO}_{4}$ treatment with improvement of fetal circulation as it cause umbilical artery vasodilation [41].

Coleman et al. [42] have found a significant relationship between the resistance index and pregnancy outcomes in 114 pregnant women at $24-22$ weeks who underwent Doppler sonography. Results of another study have showed a significant relationship between the vascular index and pregnancy outcomes, including fetal growth restriction [43], but results of our study were not in concordance with the last two studies. This difference could be due to the time of Doppler sonography in our study. There was also a control group in order to compare the two groups (treatment and control groups) in terms of resistance index and pregnancy outcomes in these studies, which could produce impressive different results.

\section{Conclusions}

- Infusion of $\mathrm{MgSO}_{4}$ significantly decreases the fetal RI, PI, SDR umbilical and increases the fetal RI, PI, SDR MCA and increases cerebroumblical ratio in- 
dices obtained with Doppler ultrasound study.

- $\mathrm{MgSO}_{4}$ significantly improves the fetoplacental blood flow.

- $\mathrm{MgSO}_{4}$ significantly increases $\mathrm{C} / \mathrm{U}$ ratio regardless the amount of liquor and the estimated fetal weight were normal or not.

\section{Acknowledgements}

The author is thankful to the Obstetrics and Gynecology Department, Faculty of Medicine, Alexandria University.

\section{Compliance with Ethics Requirements}

All Institutional and National Guidelines for the care and use of animals (insects) were followed.

\section{Author's Contributions}

DE designed the study and performed data collection and analysis. MR interpreted and supervised the Lab analysis results. NE and NH supervised the clinical examinations and US findings. DE wrote the manuscript. All authors were involved in the revision of the manuscript.

\section{Conflicts of Interest}

The author has declared no conflict of interest.

\section{References}

[1] American College of Obstetricians and Gynecologists [ACOG] (1996) Hypertension in Pregnancy. ACOG Technical Bulletin No. 219. ACOG, Washington DC.

[2] World Health Organization [WHO] (1988) Geographic Variation in the Incidence of Hypertension in Pregnancy. World Health Organization International Collaborative Study of Hypertensive Disorders of Pregnancy. American Journal of Obstetrics and Gynecology, 158, 80-83. https://doi.org/10.1016/0002-9378(88)90782-X

[3] Caritis, S., Sibai, B., Hauth, J., Lindheimer, M.D., Klebanoff, M., Thom, E., et al. (1998) Low-Dose Aspirin to Prevent Preeclampsia in Women at High Risk. National Institute of Child Health and Human Development Network of Maternal-Fetal Medicine Units. The New England Journal of Medicine, 338, 701-705. https://doi.org/10.1056/NEJM199803123381101

[4] Duckitt, K. and Harrington, D. (2005) Risk Factors for Pre-Eclampsia at Antenatal Booking: Systematic Review of Controlled Studies. BMJ (Clinical Research ed.), 330, 565. https://doi.org/10.1136/bmj.38380.674340.E0

[5] Esplin, M.S., Fausett, M.B., Fraser, A., Kerber, R., Mineau, G., Carrillo, J., et al. (2001) Paternal and Maternal Components of the Predisposition to Preeclampsia. The New England Journal of Medicine, 344, 867-872. https://doi.org/10.1056/NEJM200103223441201

[6] Roberts, J.M. and Lain, K.Y. (2002) Recent Insights into the Pathogenesis of PreEclampsia. Placenta, 23, 359-372. https://doi.org/10.1053/plac.2002.0819

[7] Sibai, B., Dekker, G. and Kupferminc, M. (2005) Pre-Eclampsia. The Lancet (London, England), 365, 785-799. https://doi.org/10.1016/S0140-6736(05)17987-2 
[8] Tuffnell, D.J., Jankowicz, D., Lindow, S.W., Lyons, G., Mason, G.C., Russell, I.F., et al. (2005) Outcomes of Severe Pre-Eclampsia/Eclampsia in Yorkshire 1999/2003. BJOG: An International Journal of Obstetrics and Gynaecology, 112, 875-880. https://doi.org/10.1111/j.1471-0528.2005.00565.x

[9] Klungsøyr, K., Morken, N.H., Irgens, L., Vollset, S.E. and Skjaerven, R. (2012) Secular Trends in the Epidemiology of Pre-Eclampsia throughout 40 Years in Norway: Prevalence, Risk Factors and Perinatal Survival. Paediatric and Perinatal Epidemiology, 26, 190-198. https://doi.org/10.1111/j.1365-3016.2012.01260.x

[10] Euser, A.G. and Cipolla, M.J. (2009) Magnesium Sulfate for the Treatment of Eclampsia: A Brief Review. Stroke, 40, 1169-1175. https://doi.org/10.1161/STROKEAHA.108.527788

[11] Witlin, A.G. and Sibai, B.M. (1998) Magnesium Sulfate Therapy in Preeclampsia and Eclampsia. Obstetrics and Gynecology, 92, 883-889.

https://doi.org/10.1097/00006250-199811000-00028

[12] Euser, A.G., Bullinger, L. and Cipolla, M.J. (2008) Magnesium Sulphate Treatment Decreases Blood-Brain Barrier Permeability during Acute Hypertension in Pregnant Rats. Experimental Physiology, 93, 254-261. https://doi.org/10.1113/expphysiol.2007.039966

[13] Hatab, M.R., Zeeman, G.G. and Twickler, D.M. (2005) The Effect of Magnesium Sulfate on Large Cerebral Artery Blood Flow in Preeclampsia. The Journal of Maternal-Fetal \& Neonatal Medicine, 17, 187-192. https://doi.org/10.1080/14767050500073050

[14] Sherman, R., Armory, P., Moody, P., Hope, T. and Mahajan, R.P. (2003) Effects of Magnesium Sulphate on Cerebral Haemodynamics in Healthy Volunteers: A Transcranial Doppler Study. British Journal of Anaesthesia, 91, 273-275. https://doi.org/10.1093/bja/aeg170

[15] Idama, T.O. and Lindow, S.W. (1998) Magnesium Sulphate: A Review of Clinical Pharmacology Applied to Obstetrics. British Journal of Obstetrics and Gynaecology, 105, 260-268. https://doi.org/10.1111/j.1471-0528.1998.tb10084.x

[16] Altman, D., Carroli, G., Duley, L., Farrell, B., Moodley, J., Neilson, J., et al. (2002) Do Women with Pre-Eclampsia, and Their Babies, Benefit from Magnesium Sulphate? The Magpie Trial: A Randomised Placebo-Controlled Trial. The Lancet (London, England), 359, 1877-1890. https://doi.org/10.1016/S0140-6736(02)08778-0

[17] Reynolds, J.D., Chestnut, D.H., Dexter, F., McGrath, J. and Penning, D.H. (1996) Magnesium Sulfate Adversely Affects Fetal Lamb Survival and Blocks Fetal Cerebral Blood Flow Response during Maternal Hemorrhage. Anesthesia and Analgesia, 83, 493-499. https://doi.org/10.1213/00000539-199609000-00009

[18] Mihu, D., Diculescu, D., Costin, N., Mihu, C.M., Blaga, L., Ciortea, R., et al. (2011) Applications of Doppler Ultrasound during Labor. Medical Ultrasonography, 13, 141-149.

[19] Baschat, A.A. and Gembruch, U. (2003) The Cerebroplacental Doppler Ratio Revisited. Ultrasound in Obstetrics \& Gynecology, 21, 124-127. https://doi.org/10.1002/uog.20

[20] Divon, M.Y. (1996) Umbilical Artery Doppler Velocimetry: Clinical Utility in High-Risk Pregnancies. American Journal of Obstetrics and Gynecology, 174, 10-14. https://doi.org/10.1016/S0002-9378(96)70365-4

[21] Ebrashy, A., Azmy, O., Ibrahim, M., Waly, M. and Edris, A. (2005) Middle Cerebral/Umbilical Artery Resistance Index Ratio as Sensitive Parameter for Fetal Well- 
Being and Neonatal Outcome in Patients with Preeclampsia: Case-Control Study. Croatian Medical Journal, 46, 821-825.

[22] Vyas, S., Nicolaides, K.H., Bower, S. and Campbell, S. (1990) Middle Cerebral Artery Flow Velocity Waveforms in Fetal Hypoxaemia. British Journal of Obstetrics and Gynaecology, 97, 797-803. https://doi.org/10.1111/j.1471-0528.1990.tb02573.x

[23] Gramellini, D., Folli, M.C., Raboni, S., Vadora, E. and Merialdi, A. (1992) Cerebral-Umbilical Doppler Ratio as a Predictor of Adverse Perinatal Outcome. Obstetrics and Gynecology, 79, 416-420. https://doi.org/10.1097/00006250-199203000-00018

[24] Bahlmann, F., Reinhard, I., Krummenauer, F., Neubert, S., Macchiella, D. and Wellek, S. (2002) Blood Flow Velocity Waveforms of the Fetal Middle Cerebral Artery in a Normal Population: Reference Values from 18 Weeks to 42 Weeks of Gestation. Journal of Perinatal Medicine, 30, 490-501. https://doi.org/10.1515/JPM.2002.077

[25] Tarzamni, M.K., Nezami, N., Gatreh-Samani, F., Vahedinia, S. and Tarzamni, M. (2009) Doppler Waveform Indices of Fetal Middle Cerebral Artery in Normal 20 to 40 Weeks Pregnancies. Archives of Iranian Medicine, 12, 29-34.

[26] Yalti, S., Oral, O., Gürbüz, B., Ozden, S. and Atar, F. (2004) Ratio of Middle Cerebral to Umbilical Artery Blood Velocity in Preeclamptic \& Hypertensive Women in the Prediction of Poor Perinatal Outcome. The Indian Journal of Medical Research, 120, 44-50.

[27] Rana, M., Amanullah, A. and Farooq, O. (2005) The Role of Umblical Artery Doppler in Detection and Management of Fetal Growth Retardation. Biomedica, 21, 4-7.

[28] Kassanos, D., Siristatidis, C., Vitoratos, N., Salamalekis, E. and Creatsas, G. (2003) The Clinical Significance of Doppler Findings in Fetal Middle Cerebral Artery during Labor. European Journal of Obstetrics, Gynecology, and Reproductive Biology, 109, 45-50. https://doi.org/10.1016/S0301-2115(02)00512-2

[29] Keeley, M.M., Wade, R.V., Laurent, S.L. and Hamann, V.D. (1993) Alterations in Maternal-Fetal Doppler Flow Velocity Waveforms in Preterm Labor Patients Undergoing Magnesium Sulfate Tocolysis. Obstetrics and Gynecology, 81, 191-194.

[30] Schroeder, B.M. (2002) ACOG Practice Bulletin on Diagnosing and Managing Preeclampsia and Eclampsia. American College of Obstetricians and Gynecologists. American Family Physician, 66, 330-331.

[31] Sibai, B.M., Caritis, S. and Hauth, J. (2003) What We Have Learned about Preeclampsia. Seminars in Perinatology, 27, 239-246. https://doi.org/10.1016/S0146-0005(03)00022-3

[32] ACOG Committee on Practice Bulletins-Obstetrics (2002) ACOG Practice Bulletin. Diagnosis and Management of Preeclampsia and Eclampsia. Number 33, January 2002. Obstetrics and Gynecology, 99, 159-167. https://doi.org/10.1097/00006250-200201000-00028

[33] Lindheimer, M.D., Taler, S.J. and Cunningham, F.G. (2008) Hypertension in Pregnancy. Journal of the American Society of Hypertension: JASH, 2, 484-494. https://doi.org/10.1016/j.jash.2008.10.001

[34] Lindheimer, M.D., Taler, S.J. and Cunningham, F.G. (2009) ASH Position Paper: Hypertension in Pregnancy. Journal of Clinical Hypertension (Greenwich, Conn.), 11, 214-225. https://doi.org/10.1111/j.1751-7176.2009.00085.x

[35] Neilson, J.P. and Alfirevic, Z. (2000) Doppler Ultrasound for Fetal Assessment in High Risk Pregnancies. The Cochrane Database of Systematic Reviews, No. 2, Cd- 
000073.

[36] Madazli, R., Uludağ, S. and Ocak, V. (2001) Doppler Assessment of Umbilical Artery, Thoracic Aorta and Middle Cerebral Artery in the Management of Pregnancies with Growth Restriction. Acta Obstetricia et Gynecologica Scandinavica, 80, 702 707. https://doi.org/10.1034/j.1600-0412.2001.080008702.x

[37] Bahado-Singh, R.O., Kovanci, E., Jeffres, A., Oz, U., Deren, O., Copel, J., et al. (1999) The Doppler Cerebroplacental Ratio and Perinatal Outcome in Intrauterine Growth Restriction. American Journal of Obstetrics and Gynecology, 180, 750-756. https://doi.org/10.1016/S0002-9378(99)70283-8

[38] Souza, A.S., Amorim, M.M., Coêlho, I.C., Lima, M.M., Noronha Neto, C. and Figueroa, J.N. (2008) Doppler of the Umbilical and Fetal Middle Cerebral Arteries after Magnesium Sulfate in Preeclampsia. Revista da Associacao Medica Brasileira (1992), 54, 232-237. https://doi.org/10.1590/S0104-42302008000300016

[39] Souza, A.S., Amorim, M.M., Coutinho, I.C., Lima, M.M., Noronha Neto, C. and Figueroa, J.N. (2010) Effect of the Loading Dose of Magnesium Sulfate $\left(\mathrm{MgSO}_{4}\right)$ on the Parameters of Doppler Flow Velocity in the Uterine, Umbilical and Middle Cerebral Arteries in Severe Preeclampsia. Hypertension in Pregnancy, 29, 123-134. https://doi.org/10.3109/10641950902875772

[40] Qiao, F., Wen, L. and Xu, J. (1995) Uteroplacental Blood Flow Monitoring by Color Doppler Flow Imaging in Pregnancy Induced Hypertension. Chinese Journal of Obstetrics and Gynecology, 30, 337-339.

[41] Makhseed, M., Jirous, J., Ahmed, M.A. and Viswanathan, D.L. (2000) Middle Cerebral Artery to Umbilical Artery Resistance Index Ratio in the Prediction of Neonatal Outcome. International Journal of Gynaecology and Obstetrics, 71, 119-125. https://doi.org/10.1016/S0020-7292(00)00262-9

[42] Coleman, M.A., McCowan, L.M. and North, R.A. (2000) Mid-Trimester Uterine Artery Doppler Screening as a Predictor of Adverse Pregnancy Outcome in HighRisk Women. Ultrasound in Obstetrics \& Gynecology, 15, 7-12. https://doi.org/10.1046/j.1469-0705.2000.00014.x

[43] Aardema, M.W., Oosterhof, H., Timmer, A., van Rooy, I. and Aarnoudse, J.G. (2001) Uterine Artery Doppler Flow and Uteroplacental Vascular Pathology in Normal Pregnancies and Pregnancies Complicated by Pre-Eclampsia and Small for Gestational Age Fetuses. Placenta, 22, 405-411. https://doi.org/10.1053/plac.2001.0676 